\title{
Sub-Acute Toxicity Assessment of a Polyherbal Product "Combo" on Liver and Kidney Function Indices in Experimental Rats
}

\author{
Azeemat Titilola Abdulazeez* ${ }^{1}$, Akolade Jubril Olayinka ${ }^{2}$, Fatimah Aluko Abubakar ${ }^{3}$ and Balogun Basheer Ajibola ${ }^{4}$ \\ ${ }^{l}$ Department of Biological Sciences, Al-Hikmah University, Ilorin, Nigeria \\ ${ }^{2}$ Biotechnology Advanced Research Centre, Sheda Science and Technology Complex, Abuja, Nigeria \\ ${ }^{3,4}$ Department of Biochemistry, University of Ilorin, Ilorin, Nigeria \\ Corresponding Author*
}

\begin{abstract}
Combo" is a standardized polyherbal drink prepared from five different medicinal plants. It is popularly used in Nigeria, mostly by women for reproductive and sexual dysfunction. Due to its widespread appeal to trying to conceive (TTC) patients and long-time abuse as an aphrodisiac, the effect of sub-acute administration of combo for 28 days on liver and kidney function indices in experimental rats was investigated. Serum biochemical indices and hematological parameters were determined and compared for significant variation with a reference group. In contrast to traditional belief among users, oral administration of Combo to rats once a day for 28 days at either 100, 200 or $300 \mathrm{mg} / \mathrm{Kg}$ bw did not lead to a significant (p < $0.001)$ reduction in body weight. There was little or no difference in all the studied biochemical parameters in comparison to the control except for slight variation at the highest dose level. There was also a significant increase in albumin concentration at all dose levels which can be linked to an increase availability of sex hormones. The study shows that the "Combo" extract has no significant adverse effect at the lower dose of 100 and $200 \mathrm{mg} / \mathrm{Kg}$ bw.
\end{abstract}

Keywords: Polyherbal, Medicinal, Sub-acute, "Combo", Biochemical, Adverse effect

\section{INTRODUCTION}

$\mathrm{I}^{\mathrm{n}}$ nfertility is a condition in which a woman is unable to conceive after a year of unprotected ongoing sexual activity (Noh et al., 2020). Infertility is a global concern that affects both genders with more emphasis on the female gender (Bakhitiyaret al., 2019). Infertility affects 5-8\% of couple worldwide with higher rates in sub - Saharan African. In Nigeria, about $10-30 \%$ of couples are affected (Mohammed-Durosinlorun et al., 2019). The causes of infertility vary according to geographical locationand socio economic condition (Deyhoulet al., 2017). Most times, infertile women in Nigeria resort to different forms of treatment such as faith based healing, orthodox and unorthodox therapies. The very high cost of orthodox fertility therapies and uncertainty of outcomes make most infertile Nigerian women to use unorthodox therapies (Turner, 2020). Herbal medicines are practiced with the use of naturally occurring plants with little or no modification for the treatment of diseases (Tilburt and Kaptchuk, 2008).Such plants are known as herbal drugs (Paal and Shukla, 2003).Humans over the years have used herbal drug for the treatment of their ailments because it is readily available in their immediate environment (Mishra et al., 2010)

Scientist due to advancement has however evolved traditional herbal medicines into modern medicines through the use of chemical adjustment and modifications. Modern medicine however comes with lots of side effects that make people prefer the use of natural compounds for treatment (Morsy, 2014). This general belief is however not always right because evidence has shown that medicinal plants can also portend a lot of hazards when used for a long period (Verschaeve and Van Staden, 2008). There are scientific shreds of evidence of toxic effects of crude plant extracts and isolated compounds (Koorbanally et al., 2006). These could arise directly from the herbs or contaminants present on the herbs during handling. Toxic effects from medicinal herbs may lead to altered body weight, organ weight, food consumption, enzyme level, and ultimately death in some instances (Chanda et al., 2105).The herbal combination "Combo" contains five different medicinal plants; garlic, ginger clove, gum arabica, and turmeric. Allium sativa is a member of the Amaryllidaceae family, commonly known as garlic. Its use as a spice is dated back thousands of years (Sidddiqui et al., 2020). The antimicrobial properties of garlic were reported as early as 1858 by Louis Pasteur leading to its use as an antiseptic during world wars (El-Azzouny et al., 2018).Other medicinal properties that have been ascertained scientifically include antioxidant, antihypertensive, antidiabetic, antiulcer, anticholinergic, antimicrobial, anticramp, and analgesic effect ( Chenedu and Jivini, 2019; Siddiqui et al., 2020).Ginger (Zingiberofficinale) is a common spicy plant belonging to the Zingiberaceae family (Sharma and Kumar, 2017). It is a widely used herb in traditional medicine. Medicinal properties that have been attributed to it include anti-inflammatory, blood pressure-lowering, antidiabetic, antimicrobial, and anti-tumor properties (Shahrajabian et al., 2019).Clove (Syzygiumaromaticum) is a medium-sized plant found in many parts of the world (Mehmood et al., 2020). It has been in use for centuries as a 
spice for foods and drinks. It has potent antioxidant and antimicrobial activities (Mounikaet al., 2020). Gum Arabica (Acacia nilotica) is a popular plant found throughout Australia, Africa, Asia, and America. It grows naturally and is of benefit to humans and animals (Lakoet al., 2020). It is a high source of polyphenol that has been shown to possess antioxidant and antifungal activities (Tahiret al., 2018).Turmeric (Curcuma longa) is a perennial spice cultivated mainly in India and other parts of Asia (Hay, 2019). It is widely used in foods and for therapeutic purposes (Soleimani, 2018). It possesses antidiabetic, antioxidant and antimicrobial activity (Umar etal., 2020)."Combo" is prepared by soaking the five medicinal plants in water for 72 hours. It is generally taken mostly by infertile women for infection treatment, weight reduction, sex and libido booster, menstrual cycle correction, and general detoxification of the body. This study aimed to evaluate the toxicological effect of "COMBO" herbal combination.

\section{METHODOLOGY}

\section{A. Combo Preparation}

The Polyherbal preparation "Combo" was purchased from a local herb vendor in Ilorin, Kwara State, Nigeria. The preparation is a thick brownish liquid with a pungent smell. The ingredients used for this Polyherbal preparation are fresh garlic, ginger, turmeric, dried clove, and Gum arabica. A known amount $(500 \mathrm{ml})$ of "combo" was placed on a water bath and evaporated slowly at a temperature of $60^{\circ} \mathrm{C}$. A gellike paste was obtained.

\section{B. Animals}

Twenty (20) albino rats of both sexes weighing $150 \mathrm{~g} \pm 5 \mathrm{~g}$ were obtained from the Animal Holdings of the Department of Biochemistry, University of Ilorin, Ilorin, Nigeria. They were housed in the animal laboratory with free access to animal feed and water with a $12 \mathrm{hr}$ light/dark cycles. This study was carried out after approval by the institutional research ethics committee of the Faculty of Natural and Applied Sciences, Al-Hikmah University, Ilorin, Nigeria.

\section{Experimental Design}

Four groups consisting of randomly assigned five animals each were used for the study; they were all fasted overnight before the commencement of the study. Three of the groups were treated orally with a reconstituted "combo" $(100,200$, and $300 \mathrm{mg} / \mathrm{kg}$ body weight) daily for 28 days. The control (4th group) was given only distilled water. The body weights of all the animals were monitored weekly. After the 28 days of treatment, animals were fasted overnight before being sacrificed; blood samples were collected. Coagulated blood was centrifuged at $3000 \mathrm{rpm}$ for five minutes. The serum was collected using a micropipette and stored at $4^{\circ} \mathrm{C}$ for biochemical analysis. Uncoagulated blood was analyzed for red blood cell (RBC), white blood cell (WBC), hemoglobin $(\mathrm{Hb})$, packed cell volume (PCV), lymphocytes, and hematological indices such as mean corpuscular volume
$(\mathrm{MCV})$, mean corpuscular hemoglobin $(\mathrm{MCH})$ and mean corpuscular hemoglobin concentration (MCHC). For biochemical parameters, the serum was analyzed for Urea:Veniamin and Vakirtzi (1970); Uric acid:Tietz (1995), Creatinine: Bartels et al. (1972), Bilirubin:Jendrassik and Grof (1938).Albumin: Doumaset al (1971), Aspartate aminotransferase (AST) and Alanine aminotransferase (ALT): Reitman and Frankel (1957), Alkaline phosphate (ALP): Wright et al (1972a), Superoxide dismutase (SOD):Misra and Fridovich (1972), Catalase (CAT): Beers and Sizer (1952).

\section{Statistical Analysis}

Obtained datawere expressed as mean \pm SEMand then subjected to analysis using one-way analysis of variance (ANOVA) followed by Tukey multiple comparisons test using graph Pad statistical Package version 6.0.

\section{RESULTS}

The initial and final bodyweight of the different groups is presented in Table I. All animals in the groups have an increased body weight at the end of the study

Table I: Body weights of rats before and after Administration of "combo" Extract

\begin{tabular}{|c|c|c|}
\hline Dose & Initial Weight $(\mathrm{g})$ & Final Weight $(\mathrm{g})$ \\
\hline Control & $127.64 \pm 1.54$ & $151.00 \pm 2.41^{*}$ \\
\hline $100 \mathrm{mg} / \mathrm{kg} \mathrm{b} w t$ & $162.17 \pm 0.86$ & $167.20 \pm 2.22$ \\
\hline $200 \mathrm{mg} / \mathrm{kg} \mathrm{b} w t$ & $155.80 \pm 3.46$ & $164.60 \pm 3.23$ \\
\hline $300 \mathrm{mg} / \mathrm{kg} \mathrm{b}$ wt & $168.21 \pm 2.75$ & $206.20 \pm 3.34^{*}$ \\
\hline
\end{tabular}

Values are mean \pm SEM of five replicate. Values in the same row with *are significantly different $(\mathrm{p}<0.05)$

Table II shows the hematological parameters of experimental animals after 28 days of treatment with "combo". The WBC and RBC count of combo treated rats were reduced when compared with the control animals; this decrease was not significantly different. $\mathrm{Hb}$ and PCV of all treated groups were also not significantly different from the control group.

Table II: Hematological indices of rats administered aqueous extract of "Combo"

Values are mean \pm SEM of five replicates.

\begin{tabular}{|c|c|c|c|c|}
\hline $\begin{array}{c}\text { Dose } \\
\mathrm{mg} / \mathrm{kg} \\
\text { B.wt }\end{array}$ & $\begin{array}{c}\text { White } \\
\text { Blood Cells } \\
(\mathrm{WBC})\end{array}$ & $\begin{array}{c}\text { Red Blood } \\
\text { Cells } \\
(\mathrm{RBC}) \\
\left(\mathrm{x} 10^{3} / \mu \mathrm{L}\right)\end{array}$ & $\begin{array}{c}\text { Hemoglobin } \\
(\mathrm{Hb}) \\
(\mathrm{g} / \mathrm{dL})\end{array}$ & $\begin{array}{c}\text { Hematocrit } \\
(\mathrm{HCT}) \\
(\%)\end{array}$ \\
\hline $\begin{array}{c}\text { Contro } \\
1\end{array}$ & $5.84 \pm 1.76$ & $5.68 \pm 1.36$ & $10.40 \pm 1.12$ & $30.44 \pm 7.00$ \\
\hline 100 & $4.56 \pm 1.02$ & $6.05 \pm 0.54$ & $10.50 \pm 0.85$ & $31.58 \pm 2.89$ \\
\hline 200 & $3.97 \pm 0.48$ & $5.81 \pm 0.57$ & $12.45 \pm 1.78$ & $29.57 \pm 2.93$ \\
\hline 300 & $3.95 \pm 1.16$ & $5.56 \pm 1.12$ & $8.87 \pm 1.76$ & $28.20 \pm 6.04$ \\
\hline
\end{tabular}

The concentration of some liver function indices (albumin, total and direct bilirubin) and kidney function indices (uric acid, Creatinine, and urea) after the 28 days administration of "Combo" is presented in Table III. The level of Albumin in 
groups treated with "Combo" extract increased significantly $(\mathrm{P}<0.05)$ when compared with the control group. Total and direct bilirubin concentrations were not significantly different from the control group and the different treatment groups except the total bilirubin that was significantly lower $(\mathrm{P}<$ $0.05)$ at $300 \mathrm{mg} / \mathrm{kg}$ body weight. Uric acid level significantly $(\mathrm{P}<0.05)$ decrease in the higher dose levels when compared with the control group. Creatinine concentration was only significantly $(\mathrm{P}<0.05)$ reduced at the highest dose level. The level of urea at all dose levels were not significantly different $(\mathrm{P}<0.05)$ from the control group.

Table III: Serum liver and kidney function indices in rats administered aqueous extract of "Combo"

\begin{tabular}{|c|c|c|c|c|c|c|}
\hline Dose & $\begin{array}{c}\text { Albumi } \\
\mathrm{n} \\
\mathrm{mg} / \mathrm{dL}\end{array}$ & $\begin{array}{c}\mathrm{TBL} \\
\mathrm{g} / \mathrm{dL}\end{array}$ & $\begin{array}{c}\mathrm{DBL} \\
\mathrm{g} / \mathrm{dL}\end{array}$ & $\begin{array}{c}\text { Uric } \\
\text { Acid } \\
\mathrm{mg} / \mathrm{dL}\end{array}$ & $\begin{array}{c}\text { Creatini } \\
\mathrm{ne} \\
\mathrm{mg} / \mathrm{dL}\end{array}$ & $\begin{array}{c}\text { Urea } \\
\mathrm{mg} / \mathrm{dL}\end{array}$ \\
\hline Control & $\begin{array}{c}15.39 \\
\pm 0.96\end{array}$ & $\begin{array}{c}52.05 \\
\pm 1.17\end{array}$ & $\begin{array}{c}20.08 \\
\pm 0.66\end{array}$ & $\begin{array}{c}2.69 \\
\pm 0.11\end{array}$ & $\begin{array}{c}4.84 \\
\pm 0.16\end{array}$ & $\begin{array}{c}72.54 \\
\pm 1.42\end{array}$ \\
\hline $\begin{array}{c}100 \\
\mathrm{mg} / \mathrm{kg} \\
\mathrm{b} \mathrm{wt}\end{array}$ & $\begin{array}{c}17.41 \pm \\
0.65^{*}\end{array}$ & $\begin{array}{c}52.06 \\
\pm 1.17\end{array}$ & $\begin{array}{c}19.91 \\
\pm 0.67\end{array}$ & $\begin{array}{c}2.724 \\
\pm 0.08\end{array}$ & $\begin{array}{c}4.17 \\
\pm 0.13\end{array}$ & $\begin{array}{c}74.59 \\
\pm 0.89\end{array}$ \\
\hline $\begin{array}{c}200 \\
\mathrm{mg} / \mathrm{kg} \\
\mathrm{b} \mathrm{wt}\end{array}$ & $17.38 \pm$ & 48.91 & 20.28 & $\begin{array}{c}2.55 \pm \\
\pm\end{array}$ & $\begin{array}{c}4.74 \\
\pm 1.57\end{array}$ & $\begin{array}{c}74.14 \\
\pm 0.33\end{array}$ \\
\hline $\begin{array}{c}300 \\
\mathrm{mg} / \mathrm{kg} \\
\mathrm{b} \mathrm{wt}\end{array}$ & $\begin{array}{c}18.72 \pm \\
0.81^{*}\end{array}$ & $\begin{array}{c}47.05 \\
\pm\end{array}$ & $\begin{array}{c}20.31 \\
\pm 0.67 *\end{array}$ & $\begin{array}{c}2.34 \pm \\
\pm 0.44\end{array}$ & $\begin{array}{c}4.12 \\
\pm 0.04 *\end{array}$ & $\begin{array}{c}69.43 \\
\pm 1.18\end{array}$ \\
\hline
\end{tabular}

Values are mean \pm standard error of the mean; $\mathrm{n}=5$; * significantly different from control $(\mathrm{p}<0.05)$.TBL: Total bilirubin; DBL: Direct bilirubin

The effect of "combo" on the activities of some enzymes is shown in Table IV following oral administration for 28 days.

The extract did not have a significant effect on the activities of ALP, ALT and AST at lower doses, there was however a significant reduction of ALT activity at the highest dose level.

Table IV: Effect of administration of "combo" on the activities of some selected enzymes in the serum of experimental rats

\begin{tabular}{|c|c|c|c|c|c|}
\hline $\begin{array}{c}\text { Dose } \\
\mathrm{mg} / \mathrm{kg} \\
\mathrm{b} \text { wt }\end{array}$ & $\begin{array}{c}\text { ALP } \\
(\mathrm{U} / \mathrm{L})\end{array}$ & $\begin{array}{c}\text { ALT } \\
(\mathrm{U} / \mathrm{L})\end{array}$ & $\begin{array}{c}\text { AST } \\
(\mathrm{U} / \mathrm{L})\end{array}$ & $\begin{array}{c}\mathrm{SOD} \\
\mathrm{nmol} / \\
\mathrm{min} / \mathrm{mL}\end{array}$ & $\begin{array}{c}\mathrm{CAT} \\
\mathrm{nmol} \\
/ \mathrm{min} / \mathrm{mL}\end{array}$ \\
\hline \multirow{2}{*}{ Control } & 39.51 & $11.93 \pm$ & $24.16 \pm$ & $2.54 \pm$ & $36.98 \pm$ \\
& \pm 2.32 & 0.60 & 0.39 & 0.08 & 0.97 \\
\hline \multirow{2}{*}{100} & 39.57 & $11.75 \pm$ & $23.80 \pm$ & $2.59 \pm$ & $35.63 \pm$ \\
& \pm 2.89 & 0.48 & 0.77 & 0.12 & 0.65 \\
\hline \multirow{2}{2}{200} & 39.23 & $11.14 \pm$ & $24.79 \pm$ & $2.49 \pm$ & $34.69 \pm$ \\
& \pm 1.59 & 0.99 & $1.96^{*}$ & 0.15 & 1.91 \\
\hline \multirow{2}{*}{300} & 37.08 & $9.45 \pm$ & $24.60 \pm$ & $2.52 \pm$ & $34.913 \pm$ \\
& \pm 1.99 & $0.47^{*}$ & 1.81 & 0.05 & 1.96 \\
\hline
\end{tabular}

Values are mean \pm standard error of the mean; $\mathrm{n}=5$; * significantly different from control $(\mathrm{p}<0.05)$.ALP: Alkaline phosphatase; ALT: Alanine transaminase; AST: Aspartate transaminase; SOD: Superoxide dismutase; CAT: Catalase

\section{DISCUSSION}

Medicinal plants are mostly used to treat diseased conditions in rural communities because they are cheaper than contemporary medicines and also exhibit similar therapeutic influence like orthodox medicines (Peprah et al., 2019). However, dosing and side effect of these plants does not always apply as it is been done for conventional medicines (Enioutina et al., 2017). The combination of medicinal plants such as COMBO to cure ailments and detoxification is a common practice in many Nigerians homes but their toxic effect is mostly unassessed. Toxicity assessment is useful in estimating any adverse effect of substances and therapeutic agents.The evaluation of hematological parameters is of importance in determining the effect of medicinal plants on blood constituents. These medicinal plants may contain toxic phytochemicals which may exert their toxic effect individually or by drug interaction (Arika et al., 2016). The non-significant reduction in the concentration of WBC, RBC, $\mathrm{Hb}$ and $\mathrm{HCT}$ at the dose levels used for 28 days indicate that Combo do not have adverse effect on the hematopoietic function of the bone marrow. These biochemical markers are crucial for accurate diagnosis, risk assessment, and treatment selection that lead to better clinical outcomes. The markers of renal function give an indication to the health status of the kidneys (Gowdaet al., 2010).An end product of protein metabolism and the Urea Cycle is urea. It is estimated that kidneys eliminate about 85 percent of urea, while gastrointestinal (GI) tract excretes the remaining 15 percent (Serianaet al., 2021). Serum urea levels increase in conditions where renal clearance decreases. The concentration of urea in all dose levels of administered Combo extract was not different significantly from the control group to indicate any obstruction in urea clearance from the kidneys. Creatinine is commonly used as an endogenous marker for glomerular function. A reduced glomerular filtration rate can lead to an increase in serum creatinine (Price and Finney, 2000). The concentration of uric acid and creatinine were similar with the control group except at the highest dose level $(300 \mathrm{mg} / \mathrm{kg} \mathrm{bw})$ where there was a significant reduction. Thus the reduced level observed in the study at the highest dose level may be because Combo extract helps to increase glomerular filtration rate thus improved excretion of metabolic waste products from the blood.

The liver is a vital organ that is constantly exposed to substances that can harm it. Albumin is a transport protein produced by the liver. When it is bound to a hormone, such as testosterone, it transports it and makes it unavailable for its hormonal function (Nandi et al., 2020).Men often have more sexual drive than women, which is ascribed to testosterone level. Boosting testosterone levels has also been linked to increased sexual drive in women (Raisanenet al., 2018).A significant increase in albumin concentration following the administration of COMBO may be attributed to its use as a sex booster as it will make more sex hormone available in its unbound state. Bilirubin is an indicator of liver functioning capacity (Xieet al., 2014). Bilirubin is the catabolic product of hemoglobin produced within the reticuloendothelial system, released in unconjugated form which enters into the liver, converted to conjugated forms bilirubin mono and diglucuronides by the enzyme UDP-glucuronyltransferase 
(Gowdaet al., 2009).Increased concentrations of indirect or unconjugated bilirubin could be the result of increased hemoglobin degradation. The reduction in total bilirubin concentration at the highest dose level observed in this study may be due to an extrahepatic obstruction. The evaluation of the activity of enzymes localized within tissues gives an insight into the toxic effects that exogenous compounds could have on them (Oloyede and Sunmonu, 2008).AST, ALT, and ALP are intracellular enzymes found in the liver and other organs; however, ALT is more specific to the liver due to its abundance in the cytoplasm of the hepatocyte (Sagguet al., 2014).

ALT levels can be raised by any type of liver cell injury, although they are most commonly associated with disorders that impact the hepatocytes, such as viral hepatitis, ischemic liver injury, and toxin-induced liver damage (Huang et al., 2012). Cirrhosis and other liver disorders are frequently associated with increase in AST activity (Thappaet al., 2007). In this study, the level of ALT was only significantly reduced at the highest dose level. This may be due to that fact that the extract does not have any inducing effect on the enzyme. A moderate increase in serum alkaline phosphatase is nonspecific, as it can occur in a range of liver and other organ-related disorders (Lowe et al., 2021).No significant difference was observed in the activity of ALP between all groups, when compared to the control indicating that COMBO extract did not induce its activities.

An imbalance between free radicals (produced during primary metabolism or in a disease state) and the antioxidant defense system causes cellular oxidative stress, which can damage body cells and cause a variety of diseases.(Ajiboyeet al., 2015; Jamshidi-Kia et al., 2020).Antioxidants are chemicals that can counteract the detrimental effects of free radicals. Low molecular weight antioxidant compounds like vitamins $\mathrm{E}$ and $\mathrm{C}$, and larger molecular weight antioxidant enzymes, both of which assist to prevent or repair damage caused by free radicals, are abundant in living cells. SOD and catalase (CAT) are two of the most significant antioxidant enzymes (Popracet al., 2017). This study shows that no significant alterations were observed in the antioxidant activities of SOD and CAT which are the first line of defense in the eradication of free radicals. The result also reveals that the administration of COMBO did not trigger any oxidative process that could lead to the activation of these enzymes.

\section{CONCLUSION}

The study shows that Combo extract do not have deleterious effects on renal and liver functions at the dose levels of 100, 200 and $300 \mathrm{mg} / \mathrm{Kgbw}$ for 28 days duration of the study.

\section{REFERENCES}

[1] Ajiboye, T. O., Alabi, K. A., Ariyo, F. A., Adeleye, A. O., Ojewuyi, O. B., Balogun, A., \&Sunmonu, T. O. (2015). 2-(2-Nitrovinyl) furan Promotes Oxidation of Cellular Proteins, Lipids, and DNA of Male Rat Liver and Kidney. Journal of Biochemical and Molecular Toxicology, 29(3), 114-122.

[2] Arika, W. M., D. W. Nyamai, M. N. Musila, M. P. Ngugi, and E.
N. M. Njagi. "Hematological markers of in vivo toxicity." Journal of Hematology \& Thromboembolic Diseases (2016).

[3] Bakhtiyar, K., Beiranvand, R., Ardalan, A. et al. An investigation of the effects of infertility on Women's quality of life: a casecontrol study. BMC Women's Health 19,114 (2019). https://doi.org/10.1186/s12905-019-0805-3

[4] Beers, R. F., \&Sizer, I. W. (1952). A spectrophotometric method for measuring the breakdown of hydrogen peroxide by catalase. $J$ Biolchem, 195(1), 133-140.

[5] Bertelli, R., Bonanni, A., Caridi, G., Canepa, A., \&Ghiggeri, G. M. (2018). Molecular and cellular mechanisms for proteinuria in minimal change disease. Frontiers in Medicine, 5, 170.

[6] Chanda, S., Parekh, J., Vaghasiya, Y., Dave, R., Baravalia, Y., \& Nair, R. (2015). Medicinal plants-from traditional use to toxicity assessment: a review. International Journal of Pharmaceutical Sciences and Research, 6(7), 2652.

[7] Deyhoul, N., Mohamaddoost, T., \&Hosseini, M. (2017). Infertility-related risk factors: a systematic review. Int $J$ Womens Health ReprodSci, 5(1), 24-29.

[8] Doumas, B. T., Watson, W. A., \& Biggs, H. G. (1971). Albumin standards and the measurement of serum albumin with bromcresol green. Clinicachimicaacta, 31(1), 87-96.

[9] El-Azzouny, M. M., El-Demerdash, A. S., Seadawy, H. G., \&Abou-Khadra, S. H. (2018). Antimicrobial effect of garlic (Allium sativum) and thyme (ZatariamultifloraBoiss) extracts on some food borne pathogens and their effect on virulence gene expression. Cellular and Molecular Biology, 64(10), 79-86.

[10] Enioutina, E. Y., Salis, E. R., Job, K. M., Gubarev, M. I., Krepkova, L. V., \& Sherwin, C. M. (2017). Herbal Medicines: challenges in the modern world. Part 5. status and current directions of complementary and alternative herbal medicine worldwide. Expert review of clinical pharmacology, 10(3), 327338.

[11] Gowda, S., Desai, P. B., Hull, V. V., Math, A. A. K., Vernekar, S. N., \&Kulkarni, S. S. (2009). A review on laboratory liver function tests. The Pan african medical journal, 3.:17 doi: $10.11604 /$ pamj.2009.3.17.125

[12] Gowda, S., Desai, P. B., Kulkarni, S. S., Hull, V. V., Math, A. A., \&Vernekar, S. N. (2010). Markers of renal function tests. North American journal of medical sciences, 2(4), 170173.).

[13] Hay, E., Lucariello, A., Contieri, M., Esposito, T., De Luca, A., Guerra, G., \&Perna, A. (2019). Therapeutic effects of turmeric in several diseases: An overview. Chemico-biological interactions, 310, 108729.

[14] Huang, H. L., Wang, Y. J., Zhang, Q. Y., Liu, B.,Wang, F. Y., Li, J. J., \& Zhu, R. Z. (2012). Hepatoprotective effects of baicalein against CCl4-induced acute liver injury in mice. World journal of gastroenterology: WJG, 18(45), 6605.

[15] Jamshidi-Kia, F., Wibowo, J. P., Elachouri, M., Masumi, R., Salehifard-Jouneghani, A., Abolhasanzadeh, Z., \&Lorigooini, Z. (2020). Battle between plants as antioxidants with free radicals in human body. Journal of Herbmed Pharmacology, 9(3), 191-199.

[16] Jendrassik, L., \&Grof, P. (1938). Colorimetric method of determination of bilirubin. Biochem Z, 297, 81-82.

[17] Koorbanally, C., Crouch, N. R., \& Mulholland, D. A. (2006). The phytochemistry and ethnobotany of the southern African genus Eucomis (Hyacinthaceae: Hyacinthoideae). Phytochemistry: Advances in Research, 69-85.

[18] Lako, J. D. W., Sube, K. L. L., Lumori, C. S. G., Yengkopiong, J. P., Utong, J. A. M., Binyason, S. A., ... \&Kheiralla, A. H. (2020). Diversity and distribution of medicinal plants in the republic of South Sudan. World Journal of Advanced Research and Reviews, 7(1), 018-031.

[19] Lowe D, Sanvictores T, John S (2021). Alkaline Phosphatase. [Updated 2020 Aug 30]. In: StatPearls [Internet]. Treasure Island (FL): StatPearls Publishing; 2021 Jan-. Available from: https://www.ncbi.nlm.nih.gov/books/NBK459201/

[20] Mehmood, Y., Farooq, U., Yousaf, H., Riaz, H., Mahmood, R. K., Nawaz, A., ...\& Khalid, I. (2020). Antiviral activity of green silver nanoparticles produced using aqueous buds extract of 
Syzygiumaromaticum. Pak. J. Pharm. Sci, 33(2), 839-845.

[21] Mishra, A. K., Gupta, A., Gupta, V., Sannd, R., \&Bansal, P. (2010). Asava and aristha: An ayurvedic medicine-An overview. Int J Pharm Biol Arch, 1(1), 24-30.

[22] Mishra, G., Srivastava, S., \&Nagori, B. P. (2010). Pharmacological and therapeutic activity of Cissusquadrangularis: an overview. International journal of pharmtech research, 2(2), 1298-1310.

[23] Misra, H. P., \&Fridovich, I. (1972). The role of superoxide anion in the autoxidation of epinephrine and a simple assay for superoxide dismutase. Journal of Biological chemistry, 247(10), 3170-3175.

[24] Mohammed-Durosinlorun, A., Adze, J., Bature, S. et al. Use and pattern of previous care received by infertile Nigerian women. Fertil Res and Pract 5, 14 (2019). https://doi.org/10.1186/s40738-019-0068-6

[25] Morsy, N. (2014). Phytochemical analysis of biologically active constituents of medicinal plants. Main Group Chemistry, 13(1), 721.

[26] Mounika, A. M. A., Sushma, M. S. M., Sidde, L. S. L., Malathi, S. M. S., \&Rajani, K. R. K. (2020). Invitro evaluation of antimicrobial activity of clove buds (eugineaaromatica). International Journal of Indigenous Herbs and Drugs, 25-33.

[27] Nandi, K., Sen, D. J., \&Saha, D. (2020). Hormones are the Masterkey in Chemical co-ordination system of body. International Journal of Pharmacy \& Life

[28] Noh, S., Go, A., Kim, D. B., Park, M., Jeon, H. W., \& Kim, B. (2020). Role of Antioxidant Natural Products in Management of Infertility: A Review of Their Medicinal Potential. Antioxidants, 9(10), 957.

[29] Oloyede, O. B., \&Sunmonu, T. O. (2008). Decrease in activities of selected rat liver enzymes following consumption of chemical effluent. Journal of Applied Sciences and Environmental Management, 12(3).

[30] Pal, S. K., \&Shukla, Y. (2003). Herbal medicine: current status and the future. Asian pacific journal of cancer prevention, 4(4), 281-288.

[31] Peprah, P., Agyemang-Duah, W., Arthur-Holmes, F., Budu, H. I., Abalo, E. M., Okwei, R., \&Nyonyo, J. (2019). 'We are nothing without herbs': a story of herbal remedies use during pregnancy in rural Ghana. BMC complementary and alternative medicine, 19(1), 1-12.

[32] Poprac, P., Jomova, K., Simunkova, M., Kollar, V., Rhodes, C. J., \&Valko, M. (2017). Targeting free radicals in oxidative stress-related human diseases. Trends in pharmacological sciences, 38(7), 592-607.

[33] Price, C. P., \& Finney, H. (2000). Developments in

[34] Raisanen, J. C., Chadwick, S. B., Michalak, N., \& van Anders, S. M. (2018). Average associations between sexual desire, testosterone, and stress in women and men over time. Archives of sexual behavior, 47(6), 1613-1631.

[35] Reitman, S., \& Frankel, S. (1957). A colorimetric method for the determination of serum glutamic oxalacetic and glutamic pyruvic transaminases. American journal of clinical pathology, 28(1), 5663.

[36] Saggu, S., Sakeran, M. I., Zidan, N., Tousson, E., Mohan, A., \&
Rehman, H. (2014). Ameliorating effect of chicory (Chichoriumintybus L.) fruit extract against 4-tert-octylphenol induced liver injury and oxidative stress in male rats. Food and chemical toxicology, 72, 138-146. Sciences, 11(10).

[37] Seriana, I., Akmal, M., Darusman, D., Wahyuni, S.,Khairan, K., \&Sugito, S. (2021). Neem Leaf (Azadirachtaindica A. Juss) Ethanolic Extract on the Liver and Kidney Function of Rats. The Scientific World Journal : 7970424-7970424.

[38] Shahrajabian, M. H., Sun, W., \& Cheng, Q. (2019). Clinical aspects and health benefits of ginger (Zingiberofficinale) in both traditional Chinese medicine and modern industry. Actaagriculturaescandinavica, section b-Soil \& Plant Science, 69(6), 546-556.

[39] Sharma, S., \& Kumar, R. (2017). Antioxidant activity, TLC and phytochemical analysis of ginger (zingiberofficinale 1.) Rhizome. Horticulture, Environment and Biotechnology, 58, 414422.

[40] Siddiqui, A. J., Danciu, C., Ashraf, S. A., Moin, A., Singh, R., Alreshidi, M., Patel, M., Jahan, S., Kumar, S., Alkhinjar, M.I., Badraoui, R., Snoussi, M. \& Adnan, M. (2020). Plants-derived biomolecules as potent antiviral phytomedicines: New insights on ethnobotanical evidences against coronaviruses. Plants, 9(9), 1244.

[41] Soleimani, V., Sahebkar, A., \&Hosseinzadeh, H. (2018). Turmeric (Curcuma longa) and its major constituent (curcumin) as nontoxic and safe substances. Phytotherapy Research, 32(6), 985-995.

[42] Tahir, H. E., Xiaobo, Z., Jiyong, S., Mahunu, G. K., Zhai, X., \&Mariod, A. A. (2018). Quality and postharvest-shelf life of cold-stored strawberry fruit as affected by gum arabic (Acacia senegal) edible coating. Journal of Food Biochemistry, 42(3), e12527.

[43] Thapa, B. R., \&Walia, A. (2007). Liver function tests and their interpretation. The Indian Journal of Pediatrics, 74(7), 663-671 the assessment of glomerular filtration rate. Clinic chimicaacta, 297(1-2), 55-66.

[44] Tietz, N. W. (1983). Clinical guide tolaboratory tests. Philadelphia, PA: WE Saunders Co.

[45] Tilburt, J. C., \&Kaptchuk, T. J. (2008). Herbal medicine research and global health: an ethical analysis. Bulletin of the World Health Organization, 86, 594-599.

[46] Turner, I. (2020). The Social Value of Children: A Cross Cultural Examination of Infertility in Japan and Nigeria (Doctoral dissertation). http://dx.doi.org/10.26153/tsw/11539

[47] Umar, N. M., Parumasivam, T., Aminu, N., \&Toh, S. M. (2020). Phytochemical and pharmacological properties of Curcuma aromaticaSalisb (wild turmeric). J. Appl. Pharm. Sci, 10, 180-194.

[48] Veniamin, M. P., \&Vakirtzi-Lemonias, C. (1970). Chemical basis of the carbamidodiacetylmicromethod for estimation of urea, citrulline, and carbamyl derivatives. Clinical chemistry, 16(1), 3-6.

[49] Verschaeve, L., \& Van Staden, J. (2008) Mutagenic and antimutagenic properties of extracts from South African traditional medicinal plants. Journal of Ethnopharmacology, 119(3), 575587.

[50] Xie, Y., Wang, M., Zhang, Y., Zhang, S., Tan, A., Gao, Y., ...\& Yang, X. (2013). Serum uric acid and non-alcoholic fatty liver disease in non-diabetic Chinese men. PLoS One, 8(7), e67152. 